\title{
Treponema diversity in root canals with endodontic failure
}

\author{
Leticia M. M. Nóbrega' \\ Maraisa G. Delboni' \\ Frederico C. Martinho' \\ Alexandre A Zaia' \\ Caio C. R. Ferraz ${ }^{1}$ \\ Brenda P. F. A. Gomes ${ }^{1}$
}

\begin{abstract}
Objective: This study sought to investigate the prevalence of eight oral Treponemas (Treponema denticola, T. amylovorum, T. maltophilum, T. medium, T. pectinovorum, T. socranskii, T. vicentii and T. lecithinolyticum) in teeth with endodontic treatment failure and periapical lesion.

Methods: Samples were taken from 40 root canals presenting endodontic failure and periapical lesion. DNA extraction was performed and Nested-PCR technique was used for the detection of Treponema species using specific primers.

Results: Treponemas was detected in $56.5 \%$ of the samples analyzed (22/39). Individual root canals yielded a maximum of 6 target Treponema species. T. denticola $(30.8 \%)$ and T. maltophilum $(30.8 \%)$ were the most frequently detected species followed by $T$. medium $(20.5 \%)$, T. socranskii $(20.5 \%), T$. pectinovorum (17.9\%) and T. vicentii (17.9\%). Positive association was verified between T. denticola and T. maltophilum such as T. medium $(\mathrm{P}<.05)$. T. lecithinolyticum was positively associated with intraradicular post $(\mathrm{P}<.05)$.

Conclusion: The present study revealed that a wide variety of Treponema species plays a role in persistent/secondary infection turning the root canal microbiota even more complex than previously described by endodontic literature. (Eur J Dent 2013;7:61-68)
\end{abstract}

Key words: Endodontic failure; microbiology; nested-PCR; bacteria; root canal

1 Department of Restorative Dentistry, Endodontics Division, Piracicaba Dental School - State University of Campinas, Piracicaba, São Paulo - BRASIL

Corresponding author: Dr. Brenda PFA Gomes Piracicaba Dental School - State University of Campinas UNICAMP, Endodontics Division, Av. Limeira 901. - Bairro Areiao, Piracicaba, São Paulo - BRASIL

CEP 13414-903

Tel: +551921065343

Fax: +55 1921065218

Email: bpgomesafop.unicamp.br

\section{INTRODUCTION}

The persistence of symptoms or the presence of periapical lesion which remains unchanged, increased or appeared after endodontic treatment suggest that endodontic retreatment is necessary. ${ }^{1-4}$ It has long been known that microorganisms resistant to instrumentation or medication (persistent infection) and those contaminating the root canal through coronary leakage Isecondary 
infection) after endodontic treatment are one of the main responsible for endodontic failures. ${ }^{5-9}$

Culture methods revealed that the bacterial etiology of post-treatment apical periodontitis is a Gram-positive bacterial infection. 2,5,10 However, molecular methods have indicated a more complex microbiota with the involvement of Gramnegative bacteria, such as Prevotella spp., Porphyromonas spp. and Treponema spp. ${ }^{7-8,11-12}$

Treponema spp., a very fastidious, Gram-negative, motile spirochetes, is known as an important periodontal pathogen isolated from the subgingival plaque. ${ }^{13-16}$ The $16 \mathrm{~S}$ rRNA-based analysis revealed an unexpected diversity of oral Treponema species in the subgingival pocket. Among these, 8 species have been identified and named: T. denticola, $T$. Vicentii, T. socranskii, T. pectinovorum, T. maltophilum, T. medium, T. amylovorum and T. lecithinolyticum. ${ }^{13-21}$

Due to the microbial similarity between periodontal pockets and root canal microbiota, some species have been detected in primary endodontic infection. ${ }^{22-24}$ Therefore, they might participate in the pathogenesis of periradicular lesions in unsuccessful endodontic treatment. ${ }^{8,25-26}$ Currently, no clinical study has focused on the investigation of different Treponema species in failed root canals treatment.

The aim of this study was to detect by nestedPCR the presence of eight species of Treponema (T. denticola, T. amylovorum, T. maltophilum, T. medium, T. socranskii, T. pectinovorum, T. vicentii, and T. lecithinolyticum) in those cases needing endodontic retreatment, in order to investigate the possible great diversity of Treponema spp. in persistence/ secondary endodontic infection,

\section{MATERIAL AND METHODS}

The present study was approved by the Research Ethics Committee of the Piracicaba Dental School (State University of Campinas, Piracicaba, São Paulo, Brazil), and informed consent was obtained from all subjects.

\section{Patient Selection}

Patients in need of endodontic retreatment were selected on the basis of clinical and radiographic examination. Patients who had received antibiotic treatment during the preceding 3 months or who had systemic disease were not included in this study.

\section{Sampling Procedure}

The methods followed for the microbiologic procedures performed in this study have been previously described. ${ }^{27,28}$ Clinical features were recorded and samples were collected from 40 teeth with endodontic failure and periapical lesion. The teeth were isolated from the oral cavity with a rubber dam, and the disinfection of their external surfaces and the surrounding field was carried out by using $30 \%$ hydrogen peroxide followed by $2.5 \%$ $\mathrm{NaOCl}$. The solutions were inactivated with $5 \%$ sodium thiosulfate to avoid interference with bacteriologic sampling. The sterility of the external surfaces of the crown was checked by taking a swab sample from the crown surface and streaking it on blood agar plates, which was incubated aerobically and anaerobically. A 2-stage access preparation was performed. The access cavity was made without the use of water spray but under manual irrigation with sterile saline solution and by using sterile high-speed diamond bur. This first stage was performed to promote a major removal of the contaminants (microorganisms and endotoxins). In the second stage before entering the pulp chamber, the access cavity was disinfected following the decontamination protocol described above. Its sterility was checked by taking swab samples of the cavity surface and streaking on to blood agar plates, with subsequent incubation at $37^{\circ} \mathrm{C}$ under both aerobic and anaerobic conditions. A new sterile bur was used, accomplished by irrigation with sterile/ endotoxin-free saline, to access the canal. Root-filling materials were removed by rotary instrumentation [Gates-glidden drills \#5, 4, 3, 2 (Dentsply-Maillefer, Ballaigues, Switzerland) and Hero-file \#20.06 (MicroMega, Besançon, France)] and $\mathrm{K}$-files in a crown-down technique without the use of chemical solvent, accomplished by irrigation with sterile/ endotoxin-free solution.

For microbial sampling, a sterile paper point was introduced into the full length of the canal las determined with a preoperative radiograph), and kept in place for $60 \mathrm{~s}$. In the cases that had been previously irrigated with saline, as many paper points as possible were used to absorb all liquid or fluid inside the canal. The paper point samples from the root canal were transferred immediately to a transport medium VMGA III and were 
kept at $-20^{\circ} \mathrm{C}$. Afterwards, the tubes containing the samples were shaken during 60 seconds and then $300 u L$ of the transport medium were used to perform DNA extraction with QIAamp DNA Minikit (Qiagen, Valencia, CA, USA) according to the manufacturer's instructions. After extraction, DNA was kept at $-20^{\circ} \mathrm{C}$.

\section{PCR}

Detection of Treponema species by Nested-

The isolated DNA was first amplified with universal prokaryotic ribosomal $16 \mathrm{~S}$ primer. This universal reaction were performed in a total volume of $50 \mathrm{uL}$ containing $10 \mathrm{uL}$ of extracted DNA; $5 \mathrm{uL}$ of 10X PCR buffer; $1.5 \mu \mathrm{L}$ of $25 \mathrm{mmol} / \mathrm{L} \mathrm{MgCl2;} 4 \mu \mathrm{L}$ of a mixture of each deoxynucleoside triphosphate $(100 \mathrm{mmol} / \mathrm{L}$ solution in a 10 -fold dilution); $1 \mu \mathrm{L}$ of 25 pmol forward-universal primer (5' GAGAGTTTGATYMTGGCTCAG 3') and $1 \mathrm{uL}$ of 25 pmol of reverseuniversal primer (5' GAAGGAGGTGWTCCARCCGCA 3'); $0,5 \mu \mathrm{L}$ of $5 \mathrm{U} / \mathrm{mL}$ Platinum Taq DNA Polymerase. The reagents were synthesized and provided by Invitrogen (Carlsbad, CA, USA). Samples were previously subjected to 4 -minute denaturation at $94^{\circ} \mathrm{C}$, followed by 30 cycles of 45 -second denaturation at $94^{\circ} \mathrm{C}, 45$-second annealing at $60^{\circ} \mathrm{Cs}, 1.5$-minute extension at $72^{\circ} \mathrm{C}$, and a final extension at $72^{\circ} \mathrm{C}$ for 15 minutes in automated thermal cycler (GenePro Bioer, Chinal.28 Positive controls were performed with standard stain, whereas negative controls corresponded to the reaction mixture without DNA.

Treponema spp. were identified by using a second nested amplification with species-specific $16 \mathrm{~S}$ rRNA primers for T. denticola, T. amylovorum, T. maltophilum, T. medium, T. socranskii, T. pectinovorum, T. vicentii, and T. lecithinolyticum. Primer sequence and cycles are shown in Table 1, as previously described by Willis et al ${ }^{29}$ The reactions were performed in a total volume of $25 \mathrm{uL}$ containing 1.5uL of universal PCR product; $2.5 \mathrm{uL}$ of $10 \mathrm{X}$ PCR buffer; $1.25 \mu \mathrm{L}$ of $25 \mathrm{mmol} / \mathrm{L} \mathrm{MgCl}_{2} ; 0.25 \mu \mathrm{L}$ of a mixture of each deoxynucleoside triphosphate (100 mmol/L solution in a 10-fold dilution); $0.25 \mu \mathrm{L}$ of each species-specific primer (25 pmol); $0.125 \mu \mathrm{L}$ of $5 \mathrm{U} / \mathrm{mL}$ Platinum Taq DNA Polymerase.

The PCR species-specific primer pairs used for detection of eight Treponema species in failed root canals as well as the amplicons size and PCR cycles are shown in Table 1.
The PCR products were electrophoresed on $1 \%$ agarose gel and tri-acetate-EDTA buffer stained with $0.5 \mathrm{uL} / \mathrm{ml}$ ethidium bromide and visualized under ultraviolet light. Positive reactions were determined by the presence of bands of the appropriate size. A $1 \mathrm{~kb}$ DNA ladder (Invitrogen) was used as size marker for universal PCR and a 100 bp DNA ladder was used for the second amplification.

\section{Statistical Analysis}

Data collected from each patient /clinical features) were entered into a spreadsheet and statistically analysed by using SPSS for Windows (SPSS, Chicago,IL, USA). Pearson's chi-square or Fisher's exact tests were chosen to determine whether there were significant statistical correlations between specific species and endodontic signs/ symptoms and between lesion size and number of bacteria, including positive and negative association between the species.

\section{RESULTS}

All samples were positive for bacterial DNA as determined by the use of ubiquitous primer except for one negative sample, which was discarded. On the other hand, no positive results were observed in the negative-control sample regarding the presence of bacterial DNA.

The following radiographic/clinical features were observed in the 39 root canals analyzed: radiolucent area (39/39), inadequate root filling or restoration (30/39); presence of spontaneous pain (5/39), tenderness to percussion (11/39), and sinus tract (6/39). Eighteen out of the 39 teeth analyzed presented intra-radicular post (Table 2).

Treponema species were detected in 56.5\% of the root canal samples analyzed (22/39). Individual root canals yielded a maximum of 6 target Treponema species, which was detected in $2.56 \%$ of the root canal samples analyzed (1/39) (Table 2). The most frequently detected species were $T$. denticola $(30.8 \%$ - 12/39), T. maltophilum $130.8 \%$ 12/39), T. medium (20.5\% - 8/39) and T. socranskii (20.5\% - 8/39), followed by T. pectinovorum $(17.9 \%$ - 7/39) and T. vicentii (17.9\% - 7/39) (Table 2). Low detection levels were observed for $T$. lecithinolyticum $(10.2 \%$ - 4/39) and T. amylovorum (7.6\% - 3/39) (Table 2). In addition, T. lecithinolyticum was positively associated with intra-radicular post $(P<.05)$. 
A combination of two or more Treponema species was detected in 18 out of the 39 root canals investigated (Table 2). Positive associations were found bewteen $T$. denticola and T. maltophilum $(\mathrm{p}=$ 0.002 , odds ratio $[O R]=11.500$, confidence bound $[\mathrm{CB}]=2.316-57.101)$ such as with $T$. medium $(\mathrm{p}=$ $0.006, \mathrm{OR}=12.500, \mathrm{CB}=2.002-78.051$ ). No correlation was found between presence of any Treponema species and development of clinical or radiographic findings $(P>.05)$.

\section{DISCUSSION}

Analysis of our data demonstrated that a wide variety of Treponema species do play a role in failed root canal treatment, particularly showing a predominance of $T$. denticola and T. maltophilum species.

Researches have shown a predominance of Gram-positive bacteria and the important role of E. faecalis in persistent/secondary infection mainly due to the resistance of this bacteria. ${ }^{2,5,10,37}$ Data concernig the detection of this species in endodontic treatment failures vary widely. Pinheiro et $\mathrm{al}^{2}{ }^{2}$ using culture technique revealed that $E$. faecalis were the most commonly isoleted microorganism in root-filled teeth with periapical lesions. On the other hand, Foschi et $\mathrm{al}^{37}$ and Fouad et $\mathrm{al}^{38}$ using PCR, detected E. faecalis in $72 \%$ and $22 \%$ of the cases, respectively. Gomes et $\mathrm{al}^{39}$ isolated E. faecalis in $42 \%$ and $76 \%$ of root-filled teeth by culture and PCR respectively. Preliminary studies of our samples showed an occurrence of $30 \%$ of $E$. faecalis by cultutre and $40 \%$ by nested-PCR.

Culture is the only method that detects microbial viability (ability to reproduce) and therefore, what grows on culture media is directly related to the number of microbial cells present in the infection. For this reason, E. faecalis has been found in great number in root-filled canals investigated by this method. However, culture depends on the viability of the bacteria and requires methodology for bacterial isolation, growth and detection. Moreover, some of the bacteria involved in endodontic infections are nutritionally fastidious and extremely sensitive to oxygen. Consequently, culture can fail to detect some microorganisms present in endodontic infections, such as Treponema spp. ${ }^{40}$ In retreatment cases the number of microorganisms is even lower and/or the number of microbial cells can be lost during the procedure to remove the previous root filling. As a consequence, the number of cells sampled can be lower than the detection rate of the culture method. ${ }^{39}$ Therefore, molecular methods that are more sensitive may be necessary to better describe the infection composition and have indicated a more complex microbiota. ${ }^{7-8,11-12,37,39}$

Table 1. PCR primer pairs used for detection of 8 Treponema species in teeth with endodontic failure by Nested-PCR.

\begin{tabular}{|c|c|c|c|}
\hline Microorganism & Primer pairs $\left(5^{\prime}-3^{\prime}\right)$ & Amplicon size & Cycles \\
\hline$T$ denticola & $\begin{array}{c}\text { F: TAA TAC CGA ATG TGC TCA TTT ACA T } \\
\text { R: TCA AAG AAG CAT TCC CTC TTC TTC } \\
\text { TTA }\end{array}$ & $316 \mathrm{bp}$ & $\begin{array}{c}\text { Initial denaturation at } 95^{\circ} \mathrm{C} \text { for } 2 \mathrm{~min} \text { and } 36 \text { cycles of: } 94^{\circ} \mathrm{C} \\
\text { for } 30 \mathrm{~s}, 60^{\circ} \mathrm{C} \text { for } 1 \mathrm{~min}, 72^{\circ} \mathrm{C} \text { for } 2 \mathrm{~min} \text { and a final step } 72^{\circ} \mathrm{C} \text { for } \\
10 \mathrm{~min} \text {. }\end{array}$ \\
\hline T amylovorum & $\begin{array}{l}\text { F: AGA GTT TGA TCC TGG CTC AG } \\
\text { R: CTC ACG CCT TTA TTC CGT GAG }\end{array}$ & $193 \mathrm{bp}$ & $\begin{array}{l}\text { Initial denaturation at } 95^{\circ} \mathrm{C} \text { for } 2 \mathrm{~min} \text { and } 36 \text { cycles of: } 94^{\circ} \mathrm{C} \\
\text { for } 30 \mathrm{~s}, 60^{\circ} \mathrm{C} \text { for } 1 \mathrm{~min}, 72^{\circ} \mathrm{C} \text { for } 2 \mathrm{~min} \text { and a final step } 72^{\circ} \mathrm{C} \text { for } \\
10 \mathrm{~min} \text {. }\end{array}$ \\
\hline$T$ maltophilum & $\begin{array}{c}\text { F: AGA GTT TGA TCC TGG CTC AG } \\
\text { R: CCT ATT GTG CTT ATT CAT CAG GC }\end{array}$ & $438 \mathrm{bp}$ & $\begin{array}{l}\text { Initial denaturation at } 95^{\circ} \mathrm{C} \text { for } 2 \mathrm{~min} \text { and } 36 \text { cycles of: } 94^{\circ} \mathrm{C} \\
\text { for } 30 \mathrm{~s}, 60^{\circ} \mathrm{C} \text { for } 1 \mathrm{~min}, 72^{\circ} \mathrm{C} \text { for } 2 \mathrm{~min} \text { and a final step } 72^{\circ} \mathrm{C} \text { for } \\
10 \mathrm{~min} \text {. }\end{array}$ \\
\hline$T$ medium & $\begin{array}{c}\text { F: AGA GTT TGA TCC TGG CTC AG } \\
\text { R: CCT TAT GAA GCA CTG AGT GTA TTC }\end{array}$ & $192 \mathrm{bp}$ & $\begin{array}{l}\text { Initial denaturation at } 95^{\circ} \mathrm{C} \text { for } 2 \mathrm{~min} \text { and } 36 \text { cycles of: } 94^{\circ} \mathrm{C} \\
\text { for } 30 \mathrm{~s}, 60^{\circ} \mathrm{C} \text { for } 1 \mathrm{~min}, 72^{\circ} \mathrm{C} \text { for } 2 \mathrm{~min} \text { and a final step } 72^{\circ} \mathrm{C} \text { for } \\
10 \mathrm{~min} \text {. }\end{array}$ \\
\hline$T$ socranskii & $\begin{array}{c}\text { F: GAT CAC TGT ATA CGG AAG GTA GAC A } \\
\text { R: TAC ACT TAT TCC TCG GAC AG }\end{array}$ & $285 \mathrm{bp}$ & $\begin{array}{l}\text { Initial denaturation at } 95^{\circ} \mathrm{C} \text { for } 2 \mathrm{~min} \text { and } 36 \text { cycles of: } 94^{\circ} \mathrm{C} \\
\text { for } 30 \mathrm{~s}, 60^{\circ} \mathrm{C} \text { for } 1 \mathrm{~min}, 72^{\circ} \mathrm{C} \text { for } 2 \mathrm{~min} \text { and a final step } 72^{\circ} \mathrm{C} \text { for } \\
10 \mathrm{~min} \text {. }\end{array}$ \\
\hline$T$ pectinovorum & $\begin{array}{c}\text { F: AGA GTT TGA TCC TGG CTC AG } \\
\text { R: ATA TAT CTC CAA CTT ATA TGA CCT }\end{array}$ & $194 \mathrm{bp}$ & $\begin{array}{c}\text { Initial denaturation at } 95^{\circ} \mathrm{C} \text { for } 2 \mathrm{~min} \text { and } 36 \text { cycles of: } 94^{\circ} \mathrm{C} \\
\text { for } 30 \mathrm{~s}, 60^{\circ} \mathrm{C} \text { for } 1 \mathrm{~min}, 72^{\circ} \mathrm{C} \text { for } 2 \mathrm{~min} \text { and a final step } 72^{\circ} \mathrm{C} \text { for } \\
10 \mathrm{~min} \text {. }\end{array}$ \\
\hline$T$ vincentii & $\begin{array}{c}\text { F: AGA GTT TGA TCC TGG CTC AG } \\
\text { R: AAT ACT TCT TAT GAA CAT TGA GAC }\end{array}$ & $193 \mathrm{bp}$ & $\begin{array}{l}\text { Initial denaturation at } 95^{\circ} \mathrm{C} \text { for } 2 \mathrm{~min} \text { and } 36 \text { cycles of: } 94^{\circ} \mathrm{C} \\
\text { for } 30 \mathrm{~s}, 60^{\circ} \mathrm{C} \text { for } 1 \mathrm{~min}, 72^{\circ} \mathrm{C} \text { for } 2 \mathrm{~min} \text { and a final step } 72^{\circ} \mathrm{C} \text { for } \\
10 \mathrm{~min} \text {. }\end{array}$ \\
\hline$T$ lecithinolyticum & $\begin{array}{l}\text { F: CTT GCT CCT TTC TGA GAG TGG CGG } \\
\text { R: ACG CAT CCG TAT CTC TAC GAA CTT }\end{array}$ & $950 \mathrm{bp}$ & $\begin{array}{c}\text { Initial denaturation at } 95^{\circ} \mathrm{C} \text { for } 2 \mathrm{~min} \text { and } 36 \text { cycles of: } 94^{\circ} \mathrm{C} \\
\text { for } 30 \mathrm{~s}, 60^{\circ} \mathrm{C} \text { for } 1 \mathrm{~min}, 72^{\circ} \mathrm{C} \text { for } 2 \mathrm{~min} \text { and a final step } 72^{\circ} \mathrm{C} \text { for } \\
10 \mathrm{~min} \text {. }\end{array}$ \\
\hline
\end{tabular}


Treponema spp. play an important role in periodontal disease..$^{13-16,21}$ and have been investigated in endodontic infections by molecular methods. ${ }^{22-24,31-32,37}$ However, little is know about this microrganism in persistent/secondary infection. Yet no clinical study has focused on the investigation of different Treponema species in root canals after endodontic treatment failure.

Species of Treponema have different virulence factors that can contribute to their pathogenicity.

Table 2. Occurrence of 8 Treponema species, clinical and radiographic features.

\begin{tabular}{|c|c|c|c|c|c|c|c|c|c|c|c|c|c|c|}
\hline \multirow{2}{*}{ Cases } & \multicolumn{8}{|c|}{ Treponema species } & \multicolumn{5}{|c|}{ Signs and Symptoms } & \multirow{2}{*}{$\mathrm{N}^{\circ}$ Species detected } \\
\hline & $\mathrm{Td}$ & Tma & Tme & Ts & $\mathrm{Tp}$ & Tv & $\mathrm{Tl}$ & $\mathrm{Ta}$ & SP & TP & ST & IRFR & $\mathrm{P}$ & \\
\hline 1 & + & + & & & & & & & + & + & + & + & & 2 \\
\hline 2 & & & & & & & & & & + & & + & + & 0 \\
\hline 3 & + & & + & & & & & & & & & & + & 2 \\
\hline 4 & & & & & & & & & & & & & & 0 \\
\hline 5 & & + & + & + & & & & & & & & & & 3 \\
\hline 6 & + & & & & + & + & & + & & & & + & & 4 \\
\hline 7 & + & & & & + & & & & & + & & + & + & 2 \\
\hline 8 & + & + & & & & & + & & & & & + & + & 3 \\
\hline 9 & + & + & + & + & + & & & + & & & & + & & 6 \\
\hline 10 & & & & & & & & & & & & + & + & 0 \\
\hline 11 & + & + & + & + & & & + & & & & & & + & 5 \\
\hline 12 & + & + & & + & & & & & & & & + & & 3 \\
\hline 13 & + & + & & & & + & & & & & + & + & & 3 \\
\hline 14 & & & & & & & & & & & & + & + & 0 \\
\hline 15 & + & & + & + & + & & & & & & & + & + & 4 \\
\hline 16 & & & + & + & & & & & & & & & & 2 \\
\hline 17 & & & & & & & & & & & + & + & & 0 \\
\hline 18 & & & & & & & & & & & & & & 0 \\
\hline 19 & & & & & & & & & & + & & + & & 0 \\
\hline 20 & & & & & & + & & & & + & & + & + & 1 \\
\hline 21 & + & + & + & + & & & + & & & + & & + & + & 5 \\
\hline 22 & & & & & & & & & + & + & & + & + & 0 \\
\hline 23 & & & & & & & & & + & + & + & + & & 0 \\
\hline 24 & & & & & & & & & & + & & + & & 0 \\
\hline 25 & & & & & & & & & & + & & + & . & 0 \\
\hline 26 & & + & & & & + & & & & & & + & & 2 \\
\hline 27 & & & & & & & & & & & + & + & + & 0 \\
\hline 28 & & + & & & & & & & + & + & & + & & 1 \\
\hline 29 & & & & & & & & & & & + & & & 0 \\
\hline 30 & & & & & + & + & & & & & & + & + & 2 \\
\hline 31 & + & + & + & + & & & & + & & & & + & . & 5 \\
\hline 32 & & & & & + & + & & & & & & & + & 2 \\
\hline 33 & & & & & & & & & + & & & + & + & 0 \\
\hline 34 & & + & & & & & + & & & & & + & + & 2 \\
\hline 35 & & & & & & + & & & & & & + & & 1 \\
\hline 36 & & & & & & & & & & & & + & + & 0 \\
\hline 37 & & & & & + & & & & & & & & & 1 \\
\hline 38 & & & & & & & & & & & & + & & 0 \\
\hline 39 & & & & & & & & & & & & + & + & 0 \\
\hline
\end{tabular}

Td - Treponema denticola; Tma - Treponema maltophilum; Tme - Treponema medium; Ts - Treponema socranskii; Tp - Treponema pectinovorum; Tv - Treponema vicentii; Tl - Treponema lecitinolyticum; Ta - Treponema amylovorum; SP - Spontaneous Pain; TP - Tenderness to Percussion; ST - Sinus Tract; IRFR - Inadequate Root Filling or Restoration; P - Intra-radicular post. 
They can produce proteolytic enzymes, adhere to and invade diverse host cells. Treponema species are endowed with motility, which allows them to penetrate the tissues, thus increasing their pathogenicity. They are also able to inhibit both lymphocyte function and polymorphonuclear neutrophils. Moreover, they have lipopolysaccharide (LPS) in their membrane as they are Gram-negative microorganisms. Their endotoxin has a significant toxic effect on the host, thus exacerbing the inflamatory response and enhancing the damage caused. ${ }^{15,16,34}$

In the current study, the positive detection of Treponema spp. in failed root canals is in agreement with the literature. ${ }^{8,25,26}$ Because of the difficulties in isolating and identifying Treponema spp., the use of nested-PCR protocol in this study was justified by the higher sensitivity and specificity of the assay when compared to the single PCR method. ${ }^{22,24}$

The frequent isolation of Treponema spp. (in more than $50 \%$ of the root canals analyzed) supports the role of such microorganisms in persistent/secondary infection.,25-26 Montagner et al24 found Treponema species in $90 \%$ of the root canals associated with abscess.

Data obtained in the present study revealed combinations of two or more Treponema species found in 18 out of the 39 root canals analyzed. The pathogenicity enhanced by additive effects is an important feature of mixed infection, ${ }^{35}$ as this may contribute to the maintenance of apical periodontitis. $2,10,24$

T. denticola (30.8\%) and T. maltophilum (30.8\%) were the most frequently detected species found in the present study. Siqueira et $\mathrm{al}^{25}$ found $T$. denticola in 11 out of the 21 primary infected root canals investigated (51.4\%) by using $16 \mathrm{~S}$ rDNA-based polymerase chain reaction (PCR). In addition, Montagner et $\mathrm{al}^{24}$ used nested-PCR and found T. denticola in 8 out of the 20 symptomatic primary infection.

It is worth to point out that no previous study had reported the participation of $T$. maltophilum in secondary infection. This species have been detected in teeth with primary endodontic infection. ${ }^{22-24}$ However, Siqueira \& Roças ${ }^{32}$ did not detect T. maltophilum in teeth with abscess of endodontic origin.

No correlation was found between the presence of a specific Treponema species and development of any clinical symptomatology in root canals with persistent/secondary infection. In contrast, the highest incidence of Treponema spp. in acute cases indicates their high pathogenicity, which may suggest the association of these species with signs and symptoms. $8,23,32,36,37$

\section{CONCLUSION}

The detection of a wide variety of Treponema species in persistent/secondary infection indicates that the root canal microbiota seems to be even more complex in teeth with endodontic treatment failure than that previously shown in the endodontic literature.

\section{ACKNOWLEDGMENTS}

This work was supported by the Brazilian agencies FAPESP (08/57551-0; 09/07760-5; 10/51113$1 ; 10 / 17877-4 ; 10 / 19136-1)$ \& CNPq (302575/2009$0 ; 150557 / 2011-6)$. The authors deny any conflicts of interest.

\section{REFERENCES}

1. Ricucci D, Grondal K, Bergenholtz G. Periapical status of root-filled teeth exposed to the oral enviroment by loss of restoration or caries. Oral Surg Oral Med Oral Pathol Oral Radiol Endod 2000;90:354-359.

2. Pinheiro ET, Gomes BPFA, Ferraz CCR, Sousa ELR, Teixeira FB, Souza-Filho FJ. Microorganisms from canals of rootfilled teeth with periapical lesions. Int Endod $J$ 2003;36:111.

3. Gomes BPFA, Pinheiro ET, Jacinto RC, Zaia AA, Ferraz CCR, Souza-filho FJ. Microbial analysis of canals of rootfilled teeth with periapical lesions using polymerase chain reaction. J Endod 2008;34:537-540.

4. Pinheiro ET, Gomes BPFA, Ferraz CCR, Teixeira FB, Zaia AA, Souza Filho FJ. Evaluation of root canal microorganisms isolated from teeth with endodontic failure and their antimicrobial susceptibility. Oral Microbiol Immunol 2003; 18:100-103.

5. Sundqvist G, Figdor D, Persson S, Sjogren U. Microbiologic analysis of teeth with failed endodontic treatment and outcome of conservative re-treatment. Oral Surg Oral Med Oral Pathol Oral Radiol Endod 1998;85:86-93.

6. Siqueira-Junior JF. Aetiology of root canal treatment failure: why well-treated teeth can fail. Int Endod $J$ 2001;34:110.

7. Siqueira-Junior JF, Roças IN. Polymerase chain reactionbased analysis of microorganisms associated with failed endodontic treatment. Oral Surg Oral Med Oral Pathol Oral Radiol Endod 2004;97:85-94. 
8. Gomes BPFA, Jacinto RC, Pinheiro ET, Sousa ELR, Zaia AA, Ferraz CCR, Souza-Filho FJ. Molecular analysis of Filifactor alocis, Tannerella forsythia and Treponema denticola associated with primary endodontic infections and failure endodontic treatment. $J$ Endod 2006;32:937-940.

9. Sauaia TS, Gomes BPFA, Pinheiro ET, Zaia AA, Ferraz CCR, Souza-Filho FJ. Microleakage evaluation of intraorifice sealing materials in endodontically treated teeth. Oral Surg Oral Med Oral Pathol Oral Radiol Endod 2006;102:242-246.

10. Molander A, Reit C, Dahlen G, Kvist T. Microbiological status of root-filled teeth with apical periodontitis. Int Endod $J$ 1998;31;1-7.

11. Gomes BPFA, Jacinto RC, Pinheiro ET, Sousa EL, Zaia AA, Ferraz CCR, Souza-Filho FJ. Porphyromonas gingivalis, Porphyromonas endodontalis, Prevotella intermedia and Prevotella nigrescens in endodontic lesions detected by culture and by PCR. Oral Microbiol Imunol 2005;20:211-215.

12. Vianna ME, Horz HP, Gomes Gomes BPFA, Conrads G. Microarrays complement culture methods for identification of bacteria in endodontic infections. Oral Microbiol Imunol 2005;20:253-258.

13. Wyss C, Choi BK, Schupbach P, Guggenheim B, Gobel UB. Treponema maltophilum sp. nov., a small oral spirochete isolated from human periodontal lesions. Int J Syst Bacteriol 1996;46:745-752.

14. Umemoto T, Nakasawa F, Hoshino E, Okada K, Fukunaga M, Namikawa I. Treponema medium sp. Nov., isolated from human subgingival dental plaque. Int $J$ Syst Bacteriol 1997;47:67-72.

15. Fenno JC, McBride BC. Virulence factor of oral Treponemes. Anaerobe 1998;4:1-17.

16. Chan ECS, McLaughlin R, Taxonomy and virulence of oral spirochetes. Oral Microbiol Imunol 2000;15:1-9.

17. Smibert RM, Genus III. Treponema Schaudinn 1905, 1728AL. In: Krieg NR, Holt JG. ed Bergey's manual os systematic bacteriolofy. Vol 1. Baltimore: Williams \& Williams. 1984. p.49-57

18. Chan EC, Siboo R, Keng T, Psarra N, Hurley R; Cheng SL; Lugovaz I. Treponema denticola (ex Brumpt 1925) sp. nov., nom. rev., and identification of new spirochete isolates from periodontal pockets. Int J Syst Bacteriol 1993;43:196-203.

19. Wyss C, Choi BK, Schupbach P, Guggenheim B, Gobel UB Treponema amylovorum sp. nov., a saccharolytic spirochete of medium size isolated from an advanced human periodontal lesion. Int J System Bacteriol 1997;47:842-845.

20. Wyss C, Choi BK, Schupbach P, Moter A, Guggenheim B, Gobel UB. Treponema lecithinolyticum sp. nov., a small saccharolytic spirochaete with phospholipase $A$ and $C$ activities associated with periodontal diseases. Int $J$ Syst Bacteriol 1999;49:1329-1339.
21. Dewhrist FE, Tamer MA, Ericson RE, Lau CN, Levanos VA, Boches SK, Galvin JL, Paster BJ. The diversity of periodontal spirochetes by $16 \mathrm{~S}$ rRNA analysis. Oral Microbiol Imunol 2000; 15: 196-202.

22. Siqueira-Junior JF, Roças IN. PCR-based identification of Treponema maltophilum, T. amylovorum, T. medium e t. lecithinolyticum in primary root canal infections. Arch Oral Biol 2003;48:495-502.

23. Baumgactner JC, Lhemaleelakul SU, Xia T. Identification of spirochetes (Treponemes) in endodontic infections. J Endod 2003;29:794-797.

24. Montagner F, Jacinto RC, Signoretti FGC, Gomes BPFA. Treponema species detected in infected root canals and acute apical abscess exudate. J Endod 2010;36:1796-1799.

25. Siqueira-Junior JF, Roças IN, Faveri A, Santos KRN. Detection of Treponema denticola in endodontic infection by $16 \mathrm{~S}$ rRNA gene-directed polymerase chain reaction. Oral Microbiol Imunol 2000;15:335-337.

26. Roças IN, Siqueira-Junior JF, Santos KRN, Coelho AMA. Red Complex (Bacteroides forsythus, Porphiromonas gingivalis, and Treponema denticolal in endodontic infections: a molecular approach. Oral Surg Oral Med Oral Pathol Oral Radiol Endod 2001;91:468-471.

27. Martinho FC, Chiesa WMM, Leite FRM, Cirelli JA, Gomes BPFA. Antigenic activity of bacterial endodontic contents from primary root canal infection with periapical lesions against macrophage in the release of interleukin-1 beta and tumor necrosis factor alpha. J Endod 201036:1467-1474.

28. Martinho FC, Chiesa WMM, Leite FRM, Cirelli JA, Gomes BPFA. Antigenicity of primary endodontic infection against macrophages by the levels of PGE2 production $J$ Endod 2011;37:602-607.

29. Gomes BPFA, Pinheiro ET, Gadê-Neto CR, Sousa ELR, Ferraz CCR, Zaia AA, Souza-Filho FJ. Microbiological examination of infect dental root canals. Oral Microbiol Imunol 2004;19:71-76.

30. Paster BJ, Boches SK, Galvin JL, Ericson RE, Lau CN, Levanos VA, Sahasrabudhe A, Dewhrist FE. Bacterial diversity in human subgingival plaque. J Bacteriol 2001;183:3770-3783.

31. Willis SG, Smith KS, Dunn VL, Gapter LA, Riviere KH, Riviere GR. Identification of seven Treponema species in health and disease-associated dental plaque by Nested-PCR. J Clin Microbiol 1999;37:867-869.

32. Siqueira-Junior JF, Roças IN. Treponema species associated with abscesses of endodontic origin. Oral Microbiol Imunol 2004;19:336-339.

33. Sakamoto M, Siqueira-Junior JF, Roças IN, Benno Y. Diversity of spirochetes in endodontic infection. J Clin Microbiol 2009;47:1352-1357. 
34. Tsai JP, Shi W. Analysis if gene expression in Treponema denticola with differential display polymerase chain reaction. Oral Microbiol Imunol 2000;15:305-308.

35. Dixon DR, Darveau RP. Lipopolysaccharide heterogeneity: innate host responses to bacterial modification of lipid a structure. J Dent Res 2005;84:584-595.

36. Foschi F, Izard J, Sasaki H, Sambri V, Prati C, Muller R, Stashenko P. Treponema denticola in disseminating endodontic infections. J Dent Res 2006;85:761-765.

37. Foshi F, Cavrini F, Montebugnoli L, Stashenko P, Sambri V, Prati. Detection of bacteria in endodontic samples by polymerase chain reaction assays and association with defined clinical signs in Italian patients. Oral Microbiol Imunol 2005;20:289-295

38. Fouad Af, Zerella J, Barry J, Spangberg LSW. Molecular detection of Enterococcus species in root canals of therapyresistant endodontic infections. Oral Surg Oral Med Oral Pathol Oral Radiol Endod 2005;99:112-118.

39. Gomes BPFA, Pinheiro ET, Sousa ELR, Jacinto RC, Zaia AA, Ferraz CCR, Souza-Filho, FJ. Enterococcus faecalis in dental root canals detected by culture and polymerase chain reaction. Oral Surg Oral Med Oral Pathol Oral Radiol Endod 2006;102:247-253.

40. Nissan R, Makkar SR, Sela MN, Stevens R. Whole genomic DNA-probe for detection of Porphyromonas endodontalis. J Endod 2000;26:217-220. 